\section{Bringing scientists to life}

\author{
Eurekas and Euphorias: The \\ Oxford Book of Scientific \\ Anecdotes \\ by Walter Gratzer \\ Oxford University Press: 2002. 312 pp. \\ $£ 16.99, \$ 28$
}

\section{Oliver Sacks}

Walter Gratzer has for years been a great stalwart of Nature, a man of lucid and encyclopaedic mind whose reviews have moved effortlessly from quantum physics to molecular biology. They are always written with elegance and wit, and are rich with literary and historical associations, for Gratzer seems perfectly at home not just with the concepts and methods of science, but with its history, its personalities, its human aspects. How do scientists come to the thoughts they have, and how may they sometimes delude themselves (and others) on the way? Indeed the subject of self-delusion was the central theme of one of Gratzer's earlier books, The Undergrowth of Science (Oxford University Press, 2000).

Eurekas and Euphorias has a much wider scope, and its 181 anecdotes cover the entire range of human genius, folly, character and accident. And anecdotes, properly told, given context and weight, are anything but superficial - some of the anecdotes here are, in effect, miniature essays. (Gratzer quotes Isaac Disraeli, father of Benjamin, who spoke of anecdotes as "minute notices of human nature and of human learning".) Gratzer has assembled a rich collection of historical incidents, conversations, fragments of autobiography and biography, and revelatory fragments, depicting moments of sudden illumination, or paralysing doubt, of intense absent-mindedness and equally intense concentration, accidents which open up wholly unexpected discoveries (there are an astonishing number of these), and incidents that cast a piercing light on the character and work of the scientist. Usually this is a good light, but we also learn some edifying stories of scientific feuds, jealousies, thefts and treacheries, even in individuals as intellectually noble as Newton.

Every anecdote is fully referenced and sourced, and one sees that there is a lifetime's reading behind Eurekas and Euphorias but Gratzer's learning is never intrusive. The range of the anecdotes he has selected defies categorization, although the physical sciences are perhaps more richly represented than the biological ones (thus in the index there are 24 references to Einstein and 18 to Rutherford, but only 9 to Darwin and 7 to Pasteur). Gratzer includes stories of work accomplished under the most adverse

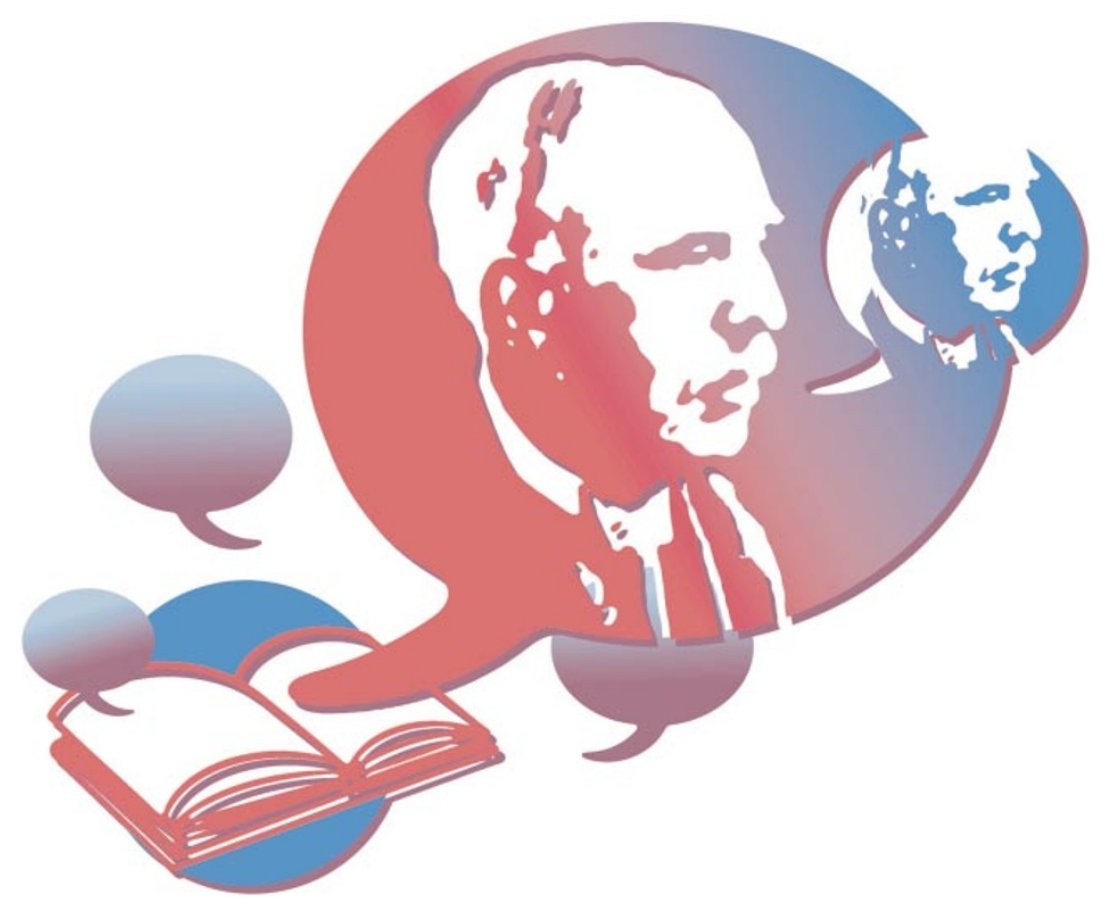

conditions - how Jean-Victor Poncelet's mathematical system was worked out in a Russian prison, and André Bloch's system when he was committed to a lunatic asylum after murdering his family.

There are delicious morsels everywhere. We are introduced to geologist and zoologist William Buckland, the first professor of zoology at Oxford, who would eat anything that came his way - not only mice en croûte, or sliced head of porpoise (from animals which had died in the zoo), but on one occasion the embalmed heart of Louis XVI. When shown a stain on a church floor of what was reputed to be the ever-renewing blood of a martyred saint, Buckland bent down, put his tongue to the floor, and diagnosed it instead as bat's urine.

We find Walther Nernst, who conceived the third law of thermodynamics, getting rid of his heat-producing cows because "a thinking man... cultivates animals that are in thermodynamic equilibrium with their surroundings and does not waste his money in heating the universe". We learn of the incredible concentration of Newton, Niels Bohr and David Hilbert; the incredible precocity of Evariste Galois and André-Marie Ampère; the brilliant rudeness of Wolfgang Pauli; the monosyllabic answers of Paul Dirac (if he answered at all). We discover how often accident has played a part, especially in the discoveries of organic chemistry, pharmacology and chemotherapy, as with the chance discovery of the role of mercury in the synthesis of indigo, or the power of mustard gas to combat leukaemia.

Reading these oddly varied, sometimes fortunate, sometimes comic and occasionally dangerous accidents, I could not help thinking of other similar ones; of how in 1845, for instance, the Swiss-German chemist Christian Schönbein, spilt a mixture of nitric and sulphuric acids in his kitchen lab one day, used his wife's cotton apron to mop it up, and then hung the apron on the stove to dry. There was a flash, a bang - and the apron disappeared. And thus the explosive nitrocellulose gun-cotton was discovered.

But one cannot paraphrase the anecdotes Gratzer tells, for then they become mere one-liners. As Gratzer tells them, these stories have context, dignity and force; they illuminate a man, his work, an era, indeed the whole conceptual and cultural structure of science.

There seems to be no systematic or explicit order to the sequence of these anecdotes, but there is clearly a rightness in their ordering, and this is Gratzer the alchemist, the artist, working invisibly behind the scenes, stringing these anecdotes together like Ezra Pound's Cantos or the movements of an opera. Here there is tension, there relaxation; here high seriousness, there levity or farce; here the sublime, there the ridiculous. But equally one can open the book at any point and be educated, thrilled, sobered or surprised, for there is astonishment and delight on every page. I, for one, will put this book next to W. H. Auden's book on aphorisms, John Bartlett's book of quotations, and that ultimate example in illustration, the great Oxford English Dictionary (OED), for finally this is a sort of OED of scientists and science, a banquet of epiphanies, a reference book which is also a work of art.

Oliver Sacks is at 2 Horatio Street 3G, New York,

New York 10014, USA and is the author of The Man Who Mistook His Wife for A Hat. 